\title{
Gambaran Pelaksanaan Mobilisasi dengan Pola Eliminasi Fekal Pasien Paska Laparatomi
}

\author{
Feki Surya Ardica ${ }^{a}$, Leni Merdawatia ${ }^{a}$ Emil Huriani ${ }^{a}$ \\ ${ }^{a}$ Fakultas Keperawatan Universitas Andalas ${ }^{\mathrm{a}}$ \\ Korespondensi : Feki Surya Ardica \\ E-mail:feki_kira@yahoo.com
}

\begin{abstract}
Patient post laparatomy just lay in bed and afraid to move because he felt pain in the scar. Constipation rate increased by 17-15\% in patients who experience physical decline because long bed rest due to surgery. Recommended 6-10 hours post-op patients should be mobilized to accelerate the recovery of organs in patients. This research determine the effect of mobilization to fecal elimination patterns in patients after laparotomy in Irna B (Surgery) RSUP Dr. M. Djamil Padang. Pre-exsperiment Research design uses post-test only design with many use 13 respondents, sampling was done in quota sampling. Data collection techniques with observation. Analysis performed univariate. Results showed that there were $92 \%$ of respondents had normal fecal elimination patterns. Expected for the nursing, institution RSUP Dr. M. Djamil padang can be suggested that the mobilization is importan post-laparotomy patients to improve teh patient's fecal elimination and revise SOP mobilization after surgery and socialized.
\end{abstract}

Key words: Mobilization, Elimination Fecal, Post-Laparatomy

\begin{abstract}
Abstrak: Pasien paska laparatomi hanya berbaring saja di tempat tidur dan takut untuk begerak karena merasa nyeri pada luka bekas operasi. Angka kejadian konstipasi meningkat sebesar $17-15 \%$ pada pasien yang mengalami penurunan fisik karena tirah baring yang lama akibat dari pembedahan. Dianjurkan 6-10 jam paska operasi pasien harus melakukan mobilisasi untuk mempercepat pemulihan organ-organ dalam pasien. Tujuan penelitian ini adalah untuk mengetahui pengaruh mobilisasi terhadap pola eliminasi fekal pada pasien paska laparatomi di Irna B (Bedah) RSUP Dr. M. Djamil Padang. Penelitian menggunakan pre- exsperiment design dengan menggunakan post test only design dengan jumlah responden sebanyak 13 orang, diambil dengan cara quota sampling. Teknik pengumpulan data dengan observasi. Analisa yang dilakukan analisa univariat. Hasil menunjukkan terdapat $92 \%$ responden mengalami pola eliminasi fekal normal. Diharapkan bagi profesi keperawatan, institusi RSUP Dr. M. Djamil padang disarankan bahwa mobilisasi penting dilakukan terhadap pasien paska laparatomi untuk meningkatkan pemenuhan kebutuhan eliminasi pasien serta merevisi SOP mobilisasi paska pembedahan dan mensosialisasikanya kepada pasien.
\end{abstract}

Kata kunci : Mobilisasi, Pola eliminasi fekal

\section{PENDAHULUAN}

Pembedahan atau operasi adalah
semua tindak pengobatan yang menggunakan cara invansif dengan membuka atau menampilkan bagian tubuh yang akan ditangani, pembukaan bagian tubuh ini umumnya dilakukan dengan membuat sayatan. Setelah bagian yang akan ditangani ditampilkan, dilakukan tindak perbaikan yang diakhiri dengan penutupan dan penjahitan (Sjamsuhidajat dan Jong 2005).

Kondisi yang paling penting diperhatikan setelah operasi laparatomi selain penyembuhan luka adalah pada sistem gastrointestinal. Dimana akibat dari anastesi umum yang dilakukan pada pasien yang dilakukan tindakan operasi bedah akan mengakibatkan terhentinya gerakan peristaltik usus untuk sementara waktu. Untuk merangsang kembali gerakan peristaltik usus maka pasien dianjurkan mobilisasi.

Apabila pasien tidak melakukan mobilisasi atau tidak dapat makan setelah pembedahan, kembalinya fungsi normal usus dapat terhambat lebih lanjut sehingga akan mengakibatkan konstipasi. Adanya 
efek anastesi umum pada tindakan pembedahan dapat menurunkan tonus otot dan menurunkan peristaltik usus (Carpenito,1995; Mubarak,2005).

Dari studi awal yang peneliti lakukan, berdasarkan hasil observasi dan wawancara dengan 5 orang pasien yang dirawat di Irna RSUP M. Djamil padang mengatakan 4 diantara 5 pasien takut melakukan mobilisasi karena merasakan nyeri bila melakukan gerakan dan pasien mengatakan mulai susah untuk BAB dan mengejan pada saat $\mathrm{BAB}$, dan 1 dari 5 orang pasien dengan konsistensi feses cair. Dari hasil wawancara dari 5 orang pasien didapatkan bahwa pasien mulai makan setelah pasien mengalami flatus dan makanan yang berikan pada pasien sesuai dengan diet yang berikan rumah sakit. Pasien hanya disuruh mobilisasi oleh perawat ruangan tanpa adanya pengawasan dari perawat itu sendiri. Dari wawancara dengan salah seorang perawat ruangan bila pasien tidak BAB maka perawat memberikan obat pencahar. Informasi yang diperoleh dari staf perawatan bedah RSUP. Dr. M. Djamil Padang pedoman khusus yang diberlakukan terhadap pasien salam melakukan mobilisasi paska laparatomi belum diadakan dan belum terlaksana.

Berdasarkan fenomena diatas peneliti tertarik untuk mengangkat penelitian tentang gambaran pelaksaan mobilisasi dengan pola eliminasi fekal pasien paska laparatomi di IRNA B (bedah) M. Djamil Padang dan Untuk mengetahui pengaruh mobilisasi terhadap pola eliminasi fekal pasien paska laparatomi di IRNA B (Bedah Umum) RSUP Dr. M. Djamil Padang.

\section{METODE}

Penelitian menggunakan preexsperiment design dengan menggunakan post test only design. Sampel adalah pasien paska laparatomi dengan anastesi umum di bangsal B (bedah) RSUP.Dr. M. Djamil padang. Teknik pengambilan sampel adalah Non probalility sampling yaitu menggunakan Quota Sampling dengan 13 orang sampel. Tehnik Quota Sampling (Saryono, 2008) yaitu cara pengambilan sampel dengan mengumpulkan subyek yang memenuhi persyaratan (subjek yang mudah ditemui) hingga terpenuhinya jumlah (quatum) yang telah ditetapkan. Penelitian sederhana mengunakan 10 sampai 20 sampel (Sugiono 2012).

\section{HASIL DAN PEMBAHASAN \\ Karakteristik Sampel}

Tabel 3 Distribusi frekwensi responden berdasarkan usia, jenis kelamin pada pasien paska laparatomi di Irna B (Bedah Umum) RSUP Dr. M. Djamil Padang Tahun 2013

\begin{tabular}{|c|c|c|}
\hline Karakteristik Responden & Frekuensi & $\%$ \\
\hline \multicolumn{3}{|l|}{ Usia } \\
\hline - Dewasa Awal (26-35) & 6 & 46,1 \\
\hline - Dewasa Akhir (36-45) & 5 & 38,5 \\
\hline - Lansia Awal (46-55) & 2 & 15,4 \\
\hline Jumlah & 13 & 10 \\
\hline Jenis Kelamin & 5 & 38,5 \\
\hline $\begin{array}{ll}\text { - } & \text { Perempuan } \\
\text { - } & \text { Laki-laki }\end{array}$ & 8 & 61,5 \\
\hline Jumlah & 13 & 100 \\
\hline
\end{tabular}


Usia

Hasil dari penelitian yang telah dilakukan menunjukkan bahwa dari 13 sampel ini, kurang dari separuh responden (46,2\%) memilki usia antara 26-35 tahun, kurang dari separuh $(38,5 \%)$ memiliki usia antara 36-45 tahun dan hampir tidak ada $(15,4 \%)$ memiliki usia 46-55 tahun.

\section{Jenis Kelamin}

Hasil dari penelitian yang telah dilakukan menunjukkan bahwa dari 13 sampel ini, lebih dari separuh $(61,5 \%)$ berjenis kelamin laki - laki dan kurang dari separuh $(38,5 \%)$ berjenis kelamin perempuan.

\section{Analisa Univariat}

Tabel 4 Distribusi frekuensi pola eliminasi pada pasien paska laparatomi yang diberikan perlakuan mobilisasi di Irna B (bedah) RSUP Dr. M. Djamil Padang tahun 2013

\begin{tabular}{lcc}
\hline \multicolumn{1}{c}{ Pola Eliminasi } & Jumlah & \% \\
\hline Normal & 12 & 92 \\
Abnormal & 1 & 8 \\
\hline Jumlah & $\mathbf{1 3}$ & $\mathbf{1 0 0}$ \\
\hline
\end{tabular}

Tabel 4 kita lihat bahwa dari 13 responden yang melaksanakan mobilisasi paska laparatomi hampir semua (92\%) yang mengalami pola eliminasi fekal normal.

Penelitian dilakukan terhadap responden paska pembedahan dengan anestesi umum di Irna B (Bedah Umum) RSUP. Dr. M. Djamil Padang selama 5 minggu yaitu mulai dari tanggal 29 April 2 juni 2013 dengan jumlah responden 13 orang yang memenuhi kriteria sampel yang telah ditentukan. Setelah peneliti mendaptkan responden berdasarkan kriteria inklusi, peneliti memberikan informasi tentang mobilisasi dan mengajarkan teknik dan cara mobilisasi 2 hari sebelum tindakan operasi dilakukan. Setelah itu peneliti meninggalkan lefleat sebagai pedoman bagi responden. Besok harinya peneliti menanyakan kembali kepada responden apakah sudah dapat memahami dan melakukan mobilisasi paska pembedahan.

Enam sampai sepuluh jam paska pembedahan responden diberikan mobilisasi sesuai pedoman dan memeriksa kondisi responden baik tanda-tanda vital responden serta memeriksa waktu kembalinya bising usus responden setelah diberikan mobilisasi dan frekuensi bising usus. Peneliti setiap hari ke rumah sakit untuk memberikan mobilisasi pada pasien dan menanyakan kepada responden apakah pasien sudah defekasi apa belum serta menanyakan konsistensi feses responden.

Dari tabel 4 dapat dilihat dari 13 orang responden yang diberikan intervensi terdapat 12 orang yang mengalami pola eliminasi fekal normal dan 1 orang mengalami pola eliminasi fekal yang abnormal. Hal ini memperlihatkan bahwa adanya pengaruh mobilisasi yang dilakukan pada responden setelah $6-10$ jam paska pembedahan terhadap pola eliminasi fekal. Gerakan yang dilakukan berupa gerakan yang dilakukan diatas tempat tempat tidur seperti teknik napas dalam, batuk terkontrol, perubahan posisi dan latihan berjalan.

Gerakan mobilisasi tersebut jika dilakukan secara bertahap, teratur dan sesuai dengan pedoman mobilisasi akan membantu memperlancar sirkulasi sehingga mempercepat pemulihan dan mempercepat pengembalian fungsi tubuh. 
Penelitian ini sejalan dengan pendapat Potter, Peterson \& Perry (2005), bahwa mobilisasi sesuai pedoman diperlukan bagi responden paska bedah. Mobilisasi sesuai pedoman tersebut dapat membantu responden dalam melakukan gerakan yang baik, teratur dan bertahap untuk mencapai tahap pemenuhan kebutuhan responden terutama kebutuhan defekasi responden.

Nofi Windiarto (2008) dalam penelitiannya tentang pengaruh mobilisasi dini terhadap pemulihan peristaltik usus pada responden yang melakukan operasi dengan anastesi umum telah membuktikan bahwa mobilisasi dini yang dilakukan dalam mengembalikan gerakan peristaltik usus responden. Wiyono (2006) dalam penelitiannya terhadap pemulihan peristaltik usus pada responden paska pembedahan mendapatkan hasil bahwa mobilisasi diperlukan bagi responden paska pembedahan untuk mempercepat pemulihan usus dan mempercepat penyembuhan responden.

Dari 13 responden yang melakukan mobilisasi, waktu tercepat pemulihan peristaltik usus dimenit 15-25 sebanyak $46,2 \%$ dan waktu terlambat pemulihan peristaltik usus di menit 40-50 sebanyak $15,4 \%$. Kemudian 4 orang responden (30\%) dengan frekuensi bising usus 32x/ menit, 4 orang responden $(30 \%)$ dengan frekuensi bising usus 29x/menit kemudian 3 orang responden $(25 \%)$ dengan frekuensi bising usus 30x/menit dan 2 orang responden $(15 \%)$ dengan frekuensi bising usus $28 \mathrm{x} /$ menit.

Hal ini sesuai dengan teori yang disampaikan oleh Telford (1999), dimana disebutkan bahwa saluran pencernaan terdiri dari 2 lapisan otot utama yaitu lapisan longitudinal yang terletak disebelah luar dan lapisan otot sirkuler yang berada disebelah dalam. Dua lapisan otot inilah yang berperan dalam mencampur dan menggerakkan makanan di saluran pencernaan. Di setiap segmen otot polos longitudinal dan sirkuler akan memperlihatkan depolarisasi spontan yang inheren. Depolarisasi inheren dapat meningkat intensitasnya dan meningkatkan potensial aksi sehingga akan terjadi proses kontraksi otot. Frekuensi kontraksi otot bervariasi, bersifat ritmik dan berjalan dalam gelombang peristaltik ke bagian distal. Juga disebutkan bahwa motilitas saluran cerna ditentukan oleh konstraksi otot serta input hormonal dan saraf. Kontraksi otot abdomen dan tekanan diafrgama serta kontraksi otot elavator akan mempengaruhi proses defekasi.

Dari hasil penelitian, pola eliminasi fekal responden setelah diberikan mobilisasi yaitu 4 kali dalam seminggu dan 10 orang responden $(76,92 \%)$ mulai defekasi pada hari 3 dan 3 orang responden $(23,08 \%)$ belum mulai defekasi. Kemudian konsistensi feses responden paska pembedahan pada hari ke 3 umumnya 10 orang responden $(76,92)$ dengan kosistensi lembek dan 3 orang responden $(23,08)$ dengan kosistensi cair dan keras. Kosistensi yang cair lebih terkait penyakit yang diderita responden dan intake cairan yang kurang dikonsumsi responden maka akan menyebabkan konsistensi keras (Carpenito, 1995). defekasi responden pada hari 1 sampai hari ke 2 tidak ada, hal ini terjadi karena responden sebelum melakukan operasi harus puasa terlebih dahulu, walaupun demikian, sisa makan didalam saluran pencernaan yang harus dikeluarkan segera dan perlu ditingkatkan agar defekasi sudah terjadi pada hari ke 2 .

Bagi 1 orang yang mengalami pola eliminasi fekal abnormal, dilihat dari karakteristik responden ini berusia 52 tahun (lansia awal). Pada lansia awal gerakan peristaltik usus menurun dan fungsi defekasi menurun karena peningkatan usia. Seiring pertambahan umur akan menyebabkan melambatnya pengosongan lambung. Ada beberapa penyebab diantaranya adalah atony (berkurangnya tonus otot yang normal) dari otot-otot polos colon yang dapat berakibat pada melambatnya peristaltik dan mengerasnya (mengering) feses, dan 
menurunnya tonus dari otot-otot perut yaitu otot dasar perineum dan sfingter anus. Jika terjadi kerusakan atau gangguan pada salah satu otot tersebut maka akan mempengaruhi proses defekasi ( Deden Dermawan \& Tutik R, 2010).

Selain itu pemulihan bising usus responden juga yang paling lama yaitu pada menit ke 50 setelah dilakukannya mobilisasi, sehingga responden terlalu lama untuk mendapatkan minum dan makan. Ditambah lagi responden juga mengalami kanker saluran pencernaan yang dapat mempengaruhi penurunan nafsu makan sehingga asupan nutrisi yang tinggi serat yang masuk berkurang. Rasa kenyang ini terjadi sekunder akibat penurunan dalam enzim-enzim pencernaan, abnormalitas dalam metabolisme glukosa dan trigliserida dan stimulasi rseptor volume lambung berkepanjangan yang menunjukkan perasaan kenyang, individu juga dapat menjadi tidak suka pada makan kerena mual dan muntah setelah tindakan laparatomi.

Pada umumnya responden kanker tidak mampu untuk mengabsorbsi nutrien dari sistem pencernaan sebagai akibat dari aktivitas tumor dan intervensi pembedahan. Intervensi pembedahan dapat mengubah pola peristaltik, ganguan sekresi saluran pencernaan yang mengakibatkan terjadinya malabsorbsi. Pernyataan ini sesuai dengan teori yang dikemukakan oleh Brunner \& Suddarth (2002), bahwa pada individu yang mengalami kanker, penurunan nafsu makan dapat terjadi karena individu merasa kenyang setelah makan- makanan yang sedikit saja.

$$
\text { Mobilisasi efektif untuk }
$$

memperlancar defekasi pada responden laparatomi dengan berbagai sistem tubuh yang terkena seperti sistem pencernaan, eliminasi maupun bagian tubuh yang bukan sistem pada rongga abdomen. Respon terhadap sistem tubuh berbedabeda terhadap obat anstesi yang diberikan, pada anastesi spinal serat otonom dan sensorik di blokir terlebih dahulu kemudian baru serat motorik, hal yang biasa terjadi pada sistem pencernaan yaitu adanya aktifitas parasimpatik yang menyebabkan peningkatan peristaltik usus ( Casey, 2000).

Tindakan pembedahan dengan anastesi umum akan menghambat hantaran aliran listrik ke otak, sehingga sel otak tidak bisa menyimpan memori atau mengenali impuls nyeri di area tubuh tertentu dan membuat responden dalam kondisi tidak sadar (loss of consciousness). Cara kerjanya selain menghilangkan rasa nyeri, menghilangkan kesadaran, dan membuat amnesia, juga merelaksasi otot akan membuat semua otot menjadi rilek. Pada sistem pencernaan akan membuat gerakan peristaltik berhenti sementara waktu yang disebabkan karena agen anastesi yang menghambat impuls saraf parasimpatis ke otot usus (Damayanti, 2010). Apabila dibiarkan berlanjut akan menggangu proses defekasi dan sistem yang lainnya pada responden paska operasi.

Berdasarkan hasil penelitian diatas, maka peneliti menyimpulkan bahwa mobilisasi efektif untuk membantu gerakan peristaltik usus responden kembali normal sehingga pola eliminasi fekal responden paska pembedahan ikut menjadi normal. Pendapat ini sesuai dengan Nofi Windiarto (2008) dalam penelitiannya tentang pengaruh mobilisasi dini terhadap pemulihan peristaltik usus pada responden yang melakukan operasi dengan anastesi umum telah membuktikan bahwa mobilisasi dini yang dilakukan dalam mengembalikan gerakan peristaltik usus responden. Kemudian Garrison (2004) menyebutkan bahwa tujuan dari mobilisasi adalah mempertahankan fungsi tubuh, memperlancar peredaran darah, membantu pernapasan menjadi lebih baik, mempertahankan tonus otot, memperlancar eliminasi BAB dan BAK, mengembalikan aktivitas tertentu sehingga responden dapat kembali normal memenuhi kebutuhan gerak harian, dan memberi kesempatan 
perawat dan responden untuk berinteraksi dan berkomunikasi.

Pelaksanaan mobilisasi yang diberikan dalam penelitian ini cukup mendapatkan respon yang baik dari responden maupun keluarga, seperti responden antusia melakukan mobilisasi karena responden telah mengetahui tujuan dilakukannya mobilisasi dan keluarga mau membantu mendampingi responden melakukan mobilisasi. Responden dan keluarga responden menyatakan dapat melakukan mobilisasi karena sudah ada panduan untuk melakukan mobilisasi yang diberikan peneliti.

\section{KESIMPULAN DAN SARAN}

Berdasarkan hasil penelitian dan pembahasan maka dapat disimpulkan bahwa dari 13 responden yang melakukan mobilisasi paska pembedahan laparatomi, 92\% mengalami pola eliminasi fekal normal dan ada kecenderungan pada responden yang melakukan mobilisasi paska pembedahan, sebagian besar mengalami pola elimnasi fekal normal. Saran dari peneliti ini adalah:

1. Perawat bedah

Diharapkan pada perawat yang bertugas diruangan bedah untuk dapat mengaplikasikan latihan mobilisasi paska pembedahan dengan memberikan edukasi dan latihan pada fase pre op.

2. Manajemen Rumah sakit

Diharapkan bagi isntitusi rumah sakit agar dapat menerapkan pelaksanaan mobilisasi dan merevisi SOP mobilisasi paska pembedahan dan mensosialisasikannya.

3. Bagi peneliti selanjutnya

Diharapakan mengadakan penelitian yang sama dengan peneliti dengan menambahkan kelompok pembanding

\section{DAFTAR PUSTAKA}

Brunner \& Suddarrtth. (2002). Keperawatan Medikal Bedah (Edisi 8). Vol. 2. Jakarta:EGC
Chandrasekaran, Kumar, David. (2009). Early Mobilization After Total Knee Replacemen Reduce the Incidence of Deep Venous Trhombosis. Vol. 79. Edisi 7-8;pg.526. ANZ Journal Of Surgery. Oxford: 2009 Juli

Condon Telford. (1999). Textbook of Surgery. Philadelia: Sounder Company.

Damayanti, Laili. (2010). Seputar Obat Anestesi: Lain Jenis, Lain Kegunaannya.

Diakses pada tanggal 16 Juni 2013 dari

www.hypnosis45.com/download/S eputar\%200bat\%20Bius.pdf

Darwis, Idral. (2007). Advance Wound Care Base On Evidence. Padang: Indonesia. Enterostotinal Therapist Nurse Association.

David dr, S. (2008). Anatomi fisiologi kulit dan penyembuhan luka. FK Universitas Airlangga. Diakses pada tanggal 5 Maret 2013

dari

http://surabayaplasticsurgery.blogs pot.com/2008/05/anatomi-fisiologi kulitdan-penyembuhan.html

Dermawan, Deden \&Rahayuningsih, Tutik. (2010). Keperawatan Medikal Bedah: Sistem Pencernaan. Edisi 1. Jogjakarta: Gosyen Publishing

Folden. Susan. L, et al.(2000). Practice Guidelines : for the management of constipation in adult. Article of Rehabilitation Nursing Foundation. http : //www.rehabnurse.org/pdhf/BowelGuidefo r.pdhf. Diakses 5 Maret 2013 Garrison, S. (2004). Dasar-Dasar Terapi dan Latihan Fisik. Hypocrates: Jakarta

Handayani, H. (2008). Perawatan Operatif. Diakses pada tanggal 5 Maret 2013 dari http//www.satff.ui.ac.id Hartono, Andry. (2006). Terapi gizi dan diet rumah sakit edisi 2. Jakarta:EGC karakata, Sumiarti. (1995). Bedah Minor. Jakarta : Hipokrates

Hawari, Dadang. (2001). Manajemen stress cemas dan depresi. Jakarta: Balai Penerbit FKUI 
Kozier, et all. (2008). Fundamental of Nursing: Concept, Process and Pratice. Vol.2. Fifth Edition. California: Addison Wesley.

Kozier, B \& Glenora Erb. Fundamentals of Nursing : Concepts and Procedures. California : Addison-Wesley. 1995

Mansjoer, A. 2000. Ilmu Kebidanan dan Kandungan Kapita Selekta Kedokteran. Edisi Ketiga. Jilid 1. Jakarta: Media Aescuilipius. FKUI.

Mubarak, W. I. (2005). Buku Ajar Kebutuhan Dasar Manusia : Teori dan Aplikai dalam Praktik. Jakarta : EGC

Mochtar, Rustam. (1992). Sinopsis obsteri, Jakarta: EGC

Notoatmodjo, S. (2010). Metodologi Penelitian. Ed. Rev. Jakarta: Rineka Cipta Notoatmodjo, S. (2003). Ilmu Kesehatan Masyarakat. Jakarta: Rineka Cipta .Pentingnya Bergerak Pasca

Operasi. www.cetrione.blogspot.com di download pada tanggal 5

Maret 2013

Potter \& Perry. (2006). Fundamental of Nursing. Jakarta: EGC

Schorck, Theodore R. (1992). Ilmu Bedah edisi 7. Jakarta : EGC

Sjamsuhidajat R, \& Wim de jong (2005). Buku Ajar Ilmu Bedah edisi 2. Jakarta:EGC

Smetzer S. C, Bare B. G. (2002). Buku Ajar Keperawatan Medikal Bedah Volume 2. Jakarta : EGC

Suyono, Slamet, dkk. (2001). Buku Ajar llmu Keperawatan Dalam. Edisi ke -3. Jakarta : Balai Penerbit FKUI

Syahlinda. (2008). Efektifitas Pedoman Mobilisasi Terhadap Penyembuhan Luka Insisi Pasca Laparatomi di IRNA B (Bedah) RSUP. M. Djamil Padang 2008, FK Universitas Andalas, Padang.

Swearingen. (2001). Keperawatan Medical Bedah. Ed.2. Jakarta; EGC.

Wiyono, Narko. (2006). Pengaruh Pedoman Ambulasi Dini Terhadap Kecepatan Pemulihan Peristaltik Usus Pasien Paska Operasi Fraktur Femur denganAnastesi Umum. 